\title{
A review of the use of methadone for the treatment of chronic noncancer pain
}

\author{
Mary E Lynch MD FRCPC
}

\begin{abstract}
ME Lynch. A review of the use of methadone for the treatment of chronic noncancer pain. Pain Res Manage 2005;10(3):133-144.

Methadone, although having been available for approximately half a century, is now receiving increasing attention in the management of chronic pain. This is due to recent research showing that methadone exhibits at least three different mechanisms of action including potent opioid agonism, N-methyl-D-aspartate antagonism and monoaminergic effects. This, along with methadone's excellent oral and rectal absorption, high bioavailability, long duration of action and low cost, make it a very attractive option for the treatment of chronic pain. The disadvantages of significant interindividual variation in pharmacokinetics, graduated dose equivalency ratios based on prerotation opioid dose when switching from another opioid, and the requirement for special exemption for prescribing methadone make it more complicated to use. The present review is intended to educate physicians interested in adding methadone to their armamentarium for assisting patients with moderate to severe pain.
\end{abstract}

Key Words: Chronic pain; Methadone; Pharmacotherapy
$\mathrm{M}$ ethadone has been available for approximately half a century (1). It is traditionally known for its role in assisting heroin addicts to exit street drug use and, in this context, its long half-life and duration of action have been known for some time. Accumulating evidence has identified a number of advantages of methadone over other opioids for the treatment of chronic pain, including agonist action at both $\mu$ and $\delta$ opioid receptors (2,3), N-methyl-D-aspartate (NMDA) antagonist activity (4-9) and the ability to inhibit the reuptake of monoamines (6). This, in addition to the pharmacoeconomic issues related to the very low cost of the widely available generic hydrochloride methadone powder $(10,11)$, have led to increased interest in the use of methadone for the treatment of cancer pain (10-15) and, more recently, neuropathic $(16,17)$ and chronic noncancer pain (18). However, methadone exhibits significant interindividual variation in pharmacokinetics and it is important for clinicians to be aware of this so that patients are not exposed to unnecessary risk. The present review is intended to serve as an overview for clinicians interested in using methadone in the treatment of chronic pain. For details, please refer to the numerous excellent reviews and studies that are referenced herein.

\section{PHARMACOLOGY}

\section{Chemistry}

Methadone is a unique synthetic opioid of the diphenylpropylamine class (14). Its structure is unrelated to standard

\section{Une analyse de l'utilisation de la méthadone dans le traitement des douleurs non cancéreuses chroniques}

\begin{abstract}
La méthadone, bien qu'elle soit disponible depuis environ un demi-siècle, attire plus d'attention dans la prise en charge des douleurs chroniques. Cet intérêt découle de recherches récentes selon lesquelles la méthadone comporte au moins trois mécanismes d'action différents, y compris un puissant agonisme des opiacés, un antagonisme $\mathrm{N}$-méthyl-D-aspartate et des effets monoaminergiques. Ce phénomène, allié à l'excellente absorption orale et rectale de la méthadone, à sa biodisponibilité élevée, à sa longue durée d'action et à son faible coût, le rend très attrayant dans le traitement des douleurs chroniques. Les inconvénients d'une variation pharmacocinétique interindividuelle marquée, des ratios d'équivalence de doses graduées fondés sur la dose d'opiacés de prérotation au moment de changer d'opiacé et le besoin d'une exemption spéciale pour prescrire de la méthadone en compliquent l'utilisation. La présente étude vise à informer les médecins intéressés à ajouter la méthadone à leur panoplie pour aider les patients ayant des douleurs modérées à graves.
\end{abstract}

alkaloid-type opioids (12). Methadone contains a single chiral carbon atom and consequently exists as two stereoisomers. Animal studies have demonstrated that the levorotatory enantiomer (levo- or 1-methadone, also called R-methadone) is the more potent analgesic with a 10 -fold higher affinity for opioid receptors than S-methadone (also called dextro- or $\mathrm{d}$-methadone). Human trials have confirmed that pain relief and suppression of withdrawal symptoms are related almost exclusively to R-methadone (19). In spite of this, methadone is available primarily in racemic form, except in Germany where the levorotatory enantiomer (ie, 1-methadone) is available and exhibits twice the potency of the racemic product $(12,19)$. In the United States (12) and Canada, methadone is available as a hydrochloride powder, which can be used for the preparation of oral, rectal and parenteral solutions.

\begin{abstract}
Absorption and distribution
Methadone is a basic and lipophilic drug that is almost completely absorbed from the gastrointestinal tract. Oral bioavailability is high at approximately $80 \%$ (12). Once absorbed, methadone is highly bound to $\alpha-1$-acid glycoprotein in plasma. There is a rapid and extensive initial distribution phase within $2 \mathrm{~h}$ to $3 \mathrm{~h}$ (15). Because of its relatively high lipid solubility, methadone is redistributed in fat stores with slow release into plasma and a prolonged elimination phase $(1,12)$. Methadone exhibits efficient transport across the bloodbrain barrier with cerebrospinal fluid concentrations at $73 \%$
\end{abstract}


TABLE 1

Pharmacokinetics, mechanism of action and comparative cost of available preparations of methadone in Canada

\begin{tabular}{|c|c|c|c|c|c|c|c|}
\hline Route & $\begin{array}{l}\text { Onset of } \\
\text { action }\end{array}$ & $\begin{array}{c}\text { Peak } \\
\text { concentration }\end{array}$ & $\begin{array}{l}\text { Duration of } \\
\text { action }\end{array}$ & $\begin{array}{c}\text { Half-life, } \\
\text { (mean } \pm \text { SD) }\end{array}$ & $\begin{array}{l}\text { Mechanism of } \\
\text { action }\end{array}$ & $\begin{array}{l}\text { Preparation } \\
\text { available }\end{array}$ & $\begin{array}{c}\text { Cost per month at a } \\
\text { dosage of } 20 \mathrm{mg} \text { every } 8 \mathrm{~h}\end{array}$ \\
\hline \multirow[t]{3}{*}{ Oral } & $30 \mathrm{~min}$ to $60 \mathrm{~min}$ & $4 \mathrm{~h}$ & $24 \mathrm{~h}$ to $48 \mathrm{~h}^{*}$ & $27 \pm 12 \mathrm{~h}$ & Opioid agonism & Generic methadone & $\$ 21.00$ liquid \\
\hline & & & & & NMDA antagonism & powder & \\
\hline & & & & & & & $\$ 226.00$ tablets \\
\hline
\end{tabular}

*With repeated dosing; †Pharmascience Inc, Canada. NMDA N-methyl-D-aspartate

of serum concentrations (20). Methadone appears in breast milk with a mean ratio of milk to plasma level of 0.44 . Infant exposure based on average milk intake has been calculated to be approximately $2.79 \%$ of the maternal dose (15). Methadone crosses the placenta. The methadone maintenance literature has identified that most neonates born to mothers on methadone maintenance will suffer withdrawal if untreated (15). Basic pharmacokinetic data are presented in Table 1.

\section{Metabolism \\ Metabolism of methadone is via N-demethylation in the liver through the cytochrome P450 (CYP450) system of isoenzymes. Methadone has no active metabolites, which provides it with another significant advantage over standard opioids such as morphine (17). The main enzyme involved is CYP3A4, with lesser involvement of CYP1A2 and CYP2D6 (15). CYP2D6 preferentially metabolizes R-methadone, while CYP1A2 and CYP3A4 metabolize both enantiomers. CYP3A4 expression varies up to 30 -fold. There is also genetic polymorphism for CYP2D6, ranging from poor to rapid metabolism. Medications can induce or inhibit these enzymes. These factors account for the large interindividual variation in methadone pharmaco- kinetics.}

\section{Elimination}

Most methadone is excreted via the fecal route and very little methadone appears in the urine. Methadone does not accumulate in patients with renal failure $(15,21)$. In a single-dose study (1), the terminal elimination half-life for methadone was found to be $33 \mathrm{~h}$ to $46 \mathrm{~h}$ in healthy subjects, and it was possibly longer in a group of heroin addicts scheduled to start a methadone maintenance program. In a controlled single-dose trial (19) of methadone in eight patients with chronic pain, the mean elimination half-life was found to be $37.5 \mathrm{~h}$ for R-methadone and $28.6 \mathrm{~h}$ for S-methadone. Clearance of methadone is increased with chronic dosing due to the autoinduction of CYP3A4. A recent review (15) quoted a single exponential half-life of $22.2 \mathrm{~h}$ due to autoinduction of metabolism. However, as reviewed above, there is significant interindividual variation in the metabolism and elimination phase half-life of methadone, with a range of $4.2 \mathrm{~h}$ to $130 \mathrm{~h}$ reported in some individuals (15).

\section{MECHANISM OF ACTION}

Similar to first-line opioids, such as codeine, morphine and hydromorphone, methadone is an agonist of $\mu$-opioid receptors. In addition, methadone exhibits greater $\delta$-opioid agonist activity than morphine $(2,3)$, leading to incomplete cross tolerance when patients are switched from conventional opioids like morphine and hydromorphone. The d-isomer of methadone can also reverse opioid tolerance when this switch is made (11).
Methadone also exhibits potent noncompetitive NMDA receptor inhibition at concentrations that are within its established clinical range $(4,5,7,8)$. This inhibition is nearly equipotent to dextromethorphan, a known NMDA antagonist $(4,15)$. NMDA receptors are members of the ligand-gated ion channel superfamily. Natural agonists for the NMDA receptor consist of the excitatory amino acids glutamate and aspartate. NMDA receptors exhibit minimal activity within pain systems under normal physiological conditions. Subsequent to insult and under conditions of chronic pain, NMDA receptors have been implicated in pain processing with generation and maintenance of central hypersensitivity $(22,23)$. The NMDA receptor has also been implicated in the development of opioid tolerance. NMDA antagonists have been demonstrated to prevent the development of opioid tolerance in rats and humans $(24,25)$. This may allow limitation of tolerance when using methadone as opposed to other opioids. Indeed, one study (5) found that $\mathrm{d}$-methadone blocks morphine tolerance and NMDA-induced hyperalgesia in animal models.

Phenanthrene opioids, such as codeine and morphine, do not block 5-hydroxytryptamine and noradrenaline uptake. Methadone has been demonstrated to inhibit 5-hydroxytryptamine (also called serotonin) and noradrenaline uptake, and the antinociceptive activity of methadone has been found to be related to both opioid and monoamine uptake activity (6).

Thus, methadone is capable of modulating chronic pain using several mechanisms including opioid agonism, NMDA antagonism and inhibition of monoaminergic reuptake. In addition, methadone is able to block opioid tolerance. Taken together, these characteristics help explain the clinical observation that when switching a patient from high doses of a conventional opioid to methadone, better relief is observed with doses of methadone that are $10 \%$ or less of the calculated equianalgesic doses (based on single-dose studies) $(11,26,27)$.

\section{CLINICAL ASPECTS}

\section{Unique characteristics of methadone}

Methadone demonstrates a lack of active metabolites, high potency and incomplete cross tolerance with other $\mu$-opioids, $(11-13)$. The lack of active metabolites is a significant advantage because opioid-induced neurotoxicity (with symptoms of myoclonus, sedation, confusion, delirium, organic hallucinosis, hyperalgesia, and nausea and vomiting), related to the accumulation of active metabolites, occurs with conventional opioids such as morphine, hydromorphone and oxycodone (15). Because of incomplete cross tolerance with conventional $\mu$-opioid agonists, methadone may control pain better in patients who have become tolerant to other opioids (13). Due to the additional NMDA antagonist action, methadone may be more effective in neuropathic pain and there is preliminary evidence to support this (10). Also, the additional monoaminergic 
TABLE 2

Studies examining equianalgesic dose ratios between $24 \mathrm{~h}$ oral morphine equivalent prerotation dosages and oral methadone

\begin{tabular}{|c|c|c|c|c|}
\hline Author (reference) & Population studied & n (rotations) & $\begin{array}{c}\text { Previous opioid dosage } \\
\text { in morphine equivalents, } \mathrm{mg} / 24 \mathrm{~h}\end{array}$ & $\begin{array}{c}\text { Ratio of oral } \\
\text { morphine to methadone }\end{array}$ \\
\hline Bruera et al (31) & Cancer patients & 65 & 2370 & 11.40 \\
\hline \multirow[t]{3}{*}{ Ripamonti et al (27) } & Cancer patients & 10 & 30 to 90 & 3.70 \\
\hline & & 20 & 90 to 300 & 7.75 \\
\hline & & 8 & $>300$ & 12.25 \\
\hline \multirow[t]{2}{*}{ Ripamonti et al (63) } & Cancer patients & 51 & 30 & 2.50 \\
\hline & & 37 & 2360 & 14.70 \\
\hline \multirow[t]{2}{*}{ Lawlor et al (32) } & Cancer patients & 7 & $<1165$ & 5.42 \\
\hline & & 7 & $>1165$ & 16.84 \\
\hline \multirow[t]{2}{*}{ Gagnon and Bruera (17) } & Cancer neuropathic pain patients & $18(22)$ & 1300 to 2054 & 10.00 \\
\hline & Nonneuropathic pain patients & $16(18)$ & 1300 to 2054 & 10.00 \\
\hline \multirow[t]{2}{*}{ Hagan and Wasylenko (28) } & Cancer patients & 29 & $<300$ & 4.60 \\
\hline & & & $>300$ & 12.70 \\
\hline Mercadante et al (29) & Cancer patients & 24 & 125 & 5.00 \\
\hline Hays and Woodroffe (18) & Chronic noncancer pain patients & 12 & 360 to 4800 & $6.00^{*}$ \\
\hline
\end{tabular}

${ }^{*} A$ ratio was not presented in this study but there was enough information to calculate a ratio. All prerotation opioid doses were converted to oral morphine equivalents. For these calculations it was assumed that hydromorphone has five times the potency of morphine, and when converting from subcutaneous dosage to oral dosage, the dosage was multiplied by two. All ratios were converted to oral morphine to oral methadone; some papers had expressed the ratio as subcutaneous hydromorphone to oral methadone

action may mean that methadone is more effective in chronic noncancer pain, whether it be neuropathic or not, and there is preliminary evidence to support this as well (18). These potential advantages must be balanced with the large interindividual variation in pharmacokinetics and a solid knowledge of the difference in required dose ratio based on previous opioid doses, both of which can contribute to toxicity due to overestimation of dose or delayed accumulation.

\section{Indications}

Considering methadone's characteristics, recent literature has identified potential roles for methadone in treating moderate to severe cancer pain, noncancer pain, nociceptive pain, neuropathic pain, mixed nociceptive and neuropathic pain, pain that has failed to respond to conventional opioids such as morphine or where conventional opioids have caused toxicity, situations in which there is a need for cost-effective analgesia, pain in patients with renal failure, and moderate to severe pain in individuals who have a history of drug abuse $(10-12,15,16,18)$. Methadone has been found to be a safe option when prescribed by physicians experienced and knowledgeable in its use (12), and it is a reasonable alternative in outpatient settings $(18,28,29)$.

There has been increased interest in the use of methadone for neuropathic pain due to its NMDA antagonist action $(10,11,16,17,30)$. In a case report $(16)$, methadone led to $70 \%$ relief of neuropathic pain arising from burn injuries that had been unrelieved by conventional opioids in combination with tricyclics or anticonvulsants. An open-label prospective trial of 18 patients with predominantly neuropathic cancer pain (10) found significant improvements in the mean pain intensity, with the majority of patients also reporting complete resolution of mechanical allodynia and lancinating pain (10). A recent randomized, placebo-controlled trial of 18 patients with neuropathic pain demonstrated that methadone $20 \mathrm{mg} /$ day was significantly more effective than placebo (30). There has been speculation that the additional NMDA antagonist mechanism of action may lead to different morphine to methadone conversion ratios in neuropathic versus non-neuropathic pain. The only study (17) to examine this question to date did not find a difference in conversion ratios between patients with neuropathic pain and patients with non-neuropathic pain. As noted by Moulin (11), methadone may be more useful than other opioid analgesics in the management of chronic neuropathic pain, but further study on this is required and randomized controlled trials examining this question are necessary.

\section{Opioid rotation}

Due to significant interindividual variation in the pharmacokinetics of methadone, the identification of the appropriate dose takes more time to determine than with conventional opioids. One of the biggest challenges is to identify the correct dosage when switching from another opioid to methadone. Previous work $(12,27,28,31,32)$ has shown that the equianalgesic dose ratio correlates with previous opioid dose, and that methadone is relatively more powerful in patients exposed to higher doses of conventional opioids such as morphine and hydromorphone. Thus, patients on lower opioid doses require relatively higher doses of methadone to achieve analgesia than patients on higher doses. Previous studies $(27,28,31,32)$ have worked toward the identification of a sliding scale of dose ratios based on previous total daily doses of morphine or hydromorphone. They have also attempted to define a protocol of how best to switch over from the previous opioid to methadone $(12,28,29)$. This literature continues to develop. In the meantime, knowledge accumulated to date has provided valuable guidance, and it is summarized below for clinicians who would like to use methadone for their patients.

Table 2 presents the literature to date regarding equianalgesic dose ratios between $24 \mathrm{~h}$ oral morphine equivalent prerotation doses and oral methadone. Taken together, the collected experiences presented in Table 2 are very helpful in identifying guidelines for dose conversion based on previous opioid dose. Thus, it is reasonable to consider a methadone conversion ratio based on a scale of prerotation morphine equivalents according to low(less than $90 \mathrm{mg} / 24 \mathrm{~h}$ ), medium- (90 mg/24 h to $300 \mathrm{mg} / 24 \mathrm{~h}$ ) 
TABLE 3

Reasonable dosage conversion ratios from morphine to methadone according to prerotation morphine oral dose

\begin{tabular}{lc}
\hline $\begin{array}{l}\text { Previous dosage of oral } \\
\text { morphine or equivalent per } \mathbf{2 4} \mathbf{~}\end{array}$ & $\begin{array}{c}\text { Recommended ratio of } \\
\text { oral morphine to oral methadone }\end{array}$ \\
\hline Less than $90 \mathrm{mg}$ & 4 \\
$90 \mathrm{mg}$ to $300 \mathrm{mg}$ & 8 \\
More than $300 \mathrm{mg}$ & 12 \\
\hline
\end{tabular}

and high-dose morphine (greater than $300 \mathrm{mg} / 24 \mathrm{~h}$ ). A reasonable approach to approximating the final methadone dose is to use a conversion ratio of $4: 1$ for patients on low-dose morphine (ie, $4 \mathrm{mg}$ morphine $=1 \mathrm{mg}$ methadone), 8:1 for moderate-dose morphine and 12:1 for high-dose morphine before rotation $(12,33)$ (Table 3$)$. Thus, a patient taking an equivalent dose of morphine $60 \mathrm{mg} / 24 \mathrm{~h}$ might reasonably be expected to require approximately $15 \mathrm{mg} / 24 \mathrm{~h}$ of methadone, a patient on $250 \mathrm{mg} / 24 \mathrm{~h}$ of morphine will require approximately $30 \mathrm{mg} / 24 \mathrm{~h}$ of methadone, a patient on $700 \mathrm{mg} / 24 \mathrm{~h}$ of morphine will require approximately $58 \mathrm{mg} / 24 \mathrm{~h}$ of methadone and so forth. Thus, the higher the previous dosage of morphine the lower the relative dosage of methadone needs to be.

Once the ratio for conversion to methadone is established, one is in a position to initiate the switchover. A number of approaches have been used (Table 4). Most authors have recommended a process of progressive substitution (12,27-29). Rapid switching from morphine to methadone has been found to be a safe and effective method in advanced cancer in patients with a poor response to morphine (29), and may be reasonable in situations of extreme pain or adverse effects in individuals who have not been on high doses of opioids previously. However, in general, it is best to proceed with a gradual progressive substitution. As presented in Table 4, the detailed work regarding rotation to methadone has been done by experts in palliative care in patients with cancer. Further studies in patients with noncancer pain are needed; however, in the meantime, it is reasonable to follow the guidelines established in cancer pain care. Thus, a three-stage protocol of gradual substitution is presented, using the dose conversion ratios presented in Table 3. At step 1, approximately one-third of the previous opioid dose will be discontinued and replaced with the appropriate dose of methadone. At step 2, the previous opioid will be decreased by a further one-third and replaced with methadone, and at step 3, the previous opioid will be discontinued and may or may not be replaced with methadone depending on pain control and side effects. At lower doses of opioid it is probable that the third increase of methadone will be necessary, at higher doses, it may not. The short-acting form of the previous opioid, morphine or hydromorphone, may be used for rescue doses every $4 \mathrm{~h}$ as necessary at a dose of approximately $10 \%$ of the total 24 h opioid dose.

In an outpatient setting, the clinician may decide to increase the length of time taken to change opioids (rotation) from the three-day schedule presented in many of the studies listed in Table 4, to a nine to 15 day schedule using intervals of three to five days, depending on pain levels, adverse effects and the individual patient. Table 5 presents examples of conversion schedules for low, medium and high prerotation opioid doses. These tables are presented as approximate guidelines and the clinician will have to adjust the doses depending on the availability of dosage forms, patient response and adverse effects.

\section{Route of administration}

Methadone results in excellent absorption via both the oral and rectal routes, and can be administered intravenously. Methadone is administered most commonly via the oral route and has been found to be safe and effective in both inpatient $(10,27,31,32)$ and outpatient settings $(18,28,34)$. It has also been demonstrated that a slow switchover to methadone using rectal suppositories is a safe, effective and low-cost alternative in cancer patients receiving high doses of opioids whose pain has been difficult to control using conventional opioids (35). There is some disagreement regarding methadone's suitability for subcutaneous administration, with some reports recommending against subcutaneous use due to pain and inflammation at the local injection site (12), and others indicating this can be managed by frequent site rotation and the use of dexamethasone or hyaluronidase and by use of a lower concentration in solution (15). Continuous epidural methadone has been used for cancer pain but it provides little advantage due to rapid absorption and accumulation of serum levels (15).

\section{Dosing}

Most patients obtain adequate analgesia when doses are administered every $8 \mathrm{~h}$ by the oral or rectal routes (12). A pilot study (36) in patients with cancer pain suggested that methadone can be safely administered using extended dose intervals of every $12 \mathrm{~h}$ in close to two-thirds of patients, and up to $24 \mathrm{~h}$ in one-third of patients. Patients 65 years of age and older may exhibit decreased clearance, but treatment of pain with methadone has been found to be safe at home even in older patients (34).

\section{Side effects}

All of the usual side effects associated with the opioid group of drugs are also possible with methadone. These include sedation, nausea, respiratory depression, clouding of consciousness, constipation and pruritis. At appropriate dosages, drug-related hallucinations and myoclonus are uncommon, and methadone is less constipating and less sedating than most conventional opioids $(12,15)$. There are reports $(37-41)$ of ventricular arrythmia associated with high doses of methadone. In one study (38), it was found that 14 of 17 patients had at least one potential risk factor for arrythmia (eg, hypokalemia or were taking a QT-prolonging drug). Another report (37) noted that two of three cases had some previous history of cardiac impairment. In a study (41) of 83 subjects on a methadone maintenance program, it was found that subjects exhibited longer QTc intervals than reference values of persons of the same sex and age. Only two of the subjects displayed a QTc interval greater than 500 ms; there was no correlation between QTc values and methadone dose. Further study is necessary to identify which patients may be at risk and at what dose levels. In the meantime, it is important to screen all patients for cardiac risk factors, and it is reasonable do an electrocardiogram in individuals who require doses of methadone above $200 \mathrm{mg} /$ day and individuals with a cardiac history. One should use caution when using methadone with agents that may prolong QTc intervals and a pretreatment electrocardiogram should be considered in these patients (Table 6).

\section{Interactions}

There are many potential drug interactions involving methadone. As presented above, the CYP450 system is involved in the metabolism of methadone and drugs that interfere with 
TABLE 4

Methods used for opioid rotation from conventional opioids to methadone

\begin{tabular}{|c|c|c|c|}
\hline Author (reference) & Patients & Protocol & Comments \\
\hline $\begin{array}{l}\text { Mercadante et al } \\
\text { (34) }\end{array}$ & $\begin{array}{l}\text { Cancer patients on } \\
\text { home palliative care } \\
\text { or in an outpatient } \\
\text { setting }\end{array}$ & $\begin{array}{l}\text { Rapid substitution of morphine with methadone using an } \\
\text { initial fixed ratio of } 5: 1 \text { (ie, } 20 \% \text { of previous dose of } \\
\text { morphine) while morphine was discontinued. The dose } \\
\text { was divided into } 3 \text { daily doses and then the dosage was } \\
\text { adjusted according to requirements. }\end{array}$ & $\begin{array}{l}\text { Patients who had been on higher dosages of prerotation } \\
\text { morphine (median } 256 \mathrm{mg} / \text { day, range } 120 \mathrm{mg} / \mathrm{day} \text { to } \\
400 \mathrm{mg} / \text { day) required reductions in the final dose; } \\
\text { patients on lower doses (median } 67 \mathrm{mg} / \mathrm{day} \text {, } \\
\text { range } 30 \mathrm{mg} / \text { day to } 90 \mathrm{mg} / \text { day) required increases; } \\
\text { and patients with a mean dosage of morphine of } \\
107 \mathrm{mg} / \text { day (range } 30 \mathrm{mg} / \text { day to } 180 \mathrm{mg} / \text { day) did } \\
\text { not require a dose change }\end{array}$ \\
\hline
\end{tabular}

Mercadante et al Cancer patients Complete substitution of morphine with methadone using a (33) referred to palliative graduated scale of dose ratios, methadone was given q8h, care units in $\quad 1 / 6$ of daily dose was used for rescue up to 3 times per $24 \mathrm{~h}$, Palermo and Milan and the dose was titrated according to the rescue dosages required: $\bullet 4: 1,<90 \mathrm{mg} /$ day;

- $8: 1,90 \mathrm{mg} /$ day to $300 \mathrm{mg} / \mathrm{day}$; and

$\cdot 12: 1,>300 \mathrm{mg} /$ day.

Switching was effective in $80 \%$ of cases over a period of 3.65 days. In 10 patients switching due to uncontrolled pain, a significant reduction in pain and an average of a $33 \%$ increase in methadone dosages was needed. In 32 patients switching because of uncontrolled pain and morphine-related adverse effects, there was significant improvements in pain control with decreased nausea and vomiting, constipation and sedation; an average dosage increase of $20 \%$ was required in this group.

Ripamonti et al Cancer patients (27)
Day 1: Morphine dosage was decreased by at least $30 \%$ and replaced by methadone administered q8h according to the following ratios: $\cdot 4: 1,30 \mathrm{mg} /$ day to $90 \mathrm{mg} /$ day; - $6: 1,90 \mathrm{mg} /$ day to $300 \mathrm{mg} /$ day; and $\cdot 8: 1,>300 \mathrm{mg} /$ day.

Day 2: If pain control was good, the morphine dosage decreased further and methadone dosage was increased only if there was moderate to severe pain. Rescue doses of short-acting opioids were used as needed.

Day 3: Morphine was discontinued, methadone was administered q8h plus an extra $10 \%$ of the daily methadone dose as an extra dose for breakthrough. Methadone dosage was titrated day by day until pain relief was obtained.
The authors noted that no patients discontinued methadone because of unwanted side effects, and methadone exhibited greater potency than previously thought. They noted that the final median dosage ratios of methadone obtained during the study were: $\cdot 3.7: 1,30 \mathrm{mg} /$ day to $90 \mathrm{mg} /$ day;

- $7.75: 1,90 \mathrm{mg} / \mathrm{day}$ to $300 \mathrm{mg} / \mathrm{day}$; and - $12.25: 1,>300 \mathrm{mg} /$ day.

\begin{tabular}{|c|c|c|}
\hline $\begin{array}{l}\text { Lawlor et al } \\
\text { (32) }\end{array}$ & Cancer patients & $\begin{array}{l}\text { Day 1: Morphine dosage was decreased by approximately } \\
30 \% \text { and replaced by methadone using a 10:1 conversion } \\
\text { administered q8h. }\end{array}$ \\
\hline
\end{tabular}

Day 2: Morphine dosage was decreased by a further 30\% and replaced with methadone.

Day 3: Remaining morphine is discontinued and replaced by methadone.

Day 1: Reduce previous opioid by $30 \%$ to $50 \%$. Replace
opioid using a 10:1 ratio.

\begin{tabular}{ll}
\hline Bruera and & $\begin{array}{l}\text { Cancer patients } \\
\text { fweeney (12) }\end{array}$ \\
& pallowed by \\
&
\end{tabular}

Day 2: Reduce by further $30 \%$ to $50 \%$ of original dosage of opioid. Increase dosage of methadone if there is moderate to severe pain. Transient pain was managed with rescue doses of short-acting opioids.

Day 3: Discontinue previous opioid. Maintain methadone dose q $8 \mathrm{~h}$ with a rescue dose of $10 \%$ of the daily methadone dose. Methadone dosage was titrated daily.
The authors found that in patients receiving $<1000 \mathrm{mg} /$ day of morphine prerotation, a ratio of 10:1 was reasonable, but in patients on a higher prerotation dosage, a ratio of $15: 1$ was better. They noted that the 3-day conversion allowed withdrawing of the morphine without adding the third increment of methadone in patients on $>1000 \mathrm{mg} /$ day.

The authors pointed out that contrary to what is expected with other opioids, toxicity occurs more frequently in patients exposed to high dosages of other opioids rather than those exposed to low dosages. Thus, greater caution is required when patients are switched to methadone from higher dosages of other opioids.

All ratios are expressed as oral morphine to methadone. $q 8 \mathrm{~h}$ Every $8 \mathrm{~h}$ dosing

TABLE 5

Sample cases for opioid rotation from conventional opioid to methadone

\begin{tabular}{|c|c|c|c|}
\hline & \multicolumn{3}{|c|}{ Prerotation opioid dosage in oral morphine equivalents (conversion ratio of morphine to methadone) } \\
\hline & $60 \mathrm{mg} /$ day $(4: 1)$ & $250 \mathrm{mg} /$ day $(8: 1)$ & 500 mg/day (12:1) \\
\hline $\begin{array}{l}\text { Stage } 1 \\
\quad(3 \text { to } 5 \text { days })\end{array}$ & $\begin{array}{l}\text { Decrease morphine to } 40 \mathrm{mg} / \mathrm{day} \\
\text { Start methadone } 5 \mathrm{mg} / \text { day }(2.5 \mathrm{mg} \mathrm{q} 12 \mathrm{~h})\end{array}$ & $\begin{array}{l}\text { Decrease morphine to } 160 \mathrm{mg} / \text { day } \\
\text { Start methadone } 12 \mathrm{mg} / \text { day in divided ( } 4 \mathrm{mg} \mathrm{q} 8 \mathrm{~h} \text { ) }\end{array}$ & $\begin{array}{l}\text { Decrease morphine to } 330 \mathrm{mg} / \mathrm{day} \\
\text { Start methadone } 15 \mathrm{mg} / \text { day ( } 5 \mathrm{mg} \text { q } 8 \mathrm{~h})\end{array}$ \\
\hline $\begin{array}{l}\text { Stage } 3 \\
\text { ( } 3 \text { to } 5 \text { days) }\end{array}$ & $\begin{array}{l}\text { Discontinue morphine } \\
\text { Increase methadone to } 15 \mathrm{mg} / \mathrm{day} \\
(5 \mathrm{mg} \text { q8h) }\end{array}$ & $\begin{array}{l}\text { Discontinue morphine } \\
\text { Increase methadone to } 30 \mathrm{mg} / \text { day ( } 10 \mathrm{mg} \text { q } 8 \mathrm{~h} \text { ) }\end{array}$ & $\begin{array}{l}\text { Discontinue morphine } \\
\text { Assess need for further dose increase final } \\
\text { dose may be approximately } 40 \mathrm{mg} / \mathrm{day} \text { to } \\
45 \mathrm{mg} / \mathrm{day}(13 \mathrm{mg} / \text { day to } 15 \mathrm{mg} \mathrm{q} 8 \mathrm{~h})\end{array}$ \\
\hline Rescue dose & $\begin{array}{l}\text { Morphine } 6 \mathrm{mg} \text { q4h as needed } \\
\text { (maximum } 4 \text { doses/day) }\end{array}$ & $\begin{array}{l}\text { Morphine } 25 \mathrm{mg} \text { q } 4 \mathrm{~h} \text { as needed (maximum } \\
4 \text { doses/day) }\end{array}$ & $\begin{array}{l}\text { Morphine } 50 \mathrm{mg} \text { q4h as needed (maximum } \\
4 \text { doses/day) }\end{array}$ \\
\hline
\end{tabular}

All doses refer to oral route of delivery. q4h Every $4 h$ dosing; q8h Every $8 h$ dosing; q12h Every $12 h$ dosing 
TABLE 6

QTC interval prolongation and methadone

\begin{tabular}{|c|c|c|}
\hline \multicolumn{3}{|c|}{ QTC-prolonging medications with risk of torsade de pointes* } \\
\hline Anticancer & & Tamoxifen \\
\hline \multirow[t]{11}{*}{ Anti-infective } & Macrolides & Clarithromycin \\
\hline & & Erythromycin \\
\hline & & Azithromycin \\
\hline & Floxins & Gatifloxin \\
\hline & & Levofloxin \\
\hline & & Moxifloxin \\
\hline & Antivirals & Amantadine \\
\hline & & Foscarnet \\
\hline & Antimalarials & Chloroquine \\
\hline & & Halofantrine hydrochloride \\
\hline & $\begin{array}{l}\text { Pneumocystis } \\
\text { prophylaxis }\end{array}$ & Pentamidine \\
\hline \multirow{10}{*}{ Cardiac } & Antianginal & Bepridil \\
\hline & Antiarrhythmics & Amiodarone \\
\hline & & Disopyramide \\
\hline & & Flecainide \\
\hline & & Ibutilide acetate \\
\hline & & Procainamide \\
\hline & & Quinidine \\
\hline & & Sotalol \\
\hline & Antihypertensive & Nicardipine \\
\hline & Diuretic & Indapamide \\
\hline Endocrine & Somatostatin analogue & Octreotide \\
\hline \multirow[t]{6}{*}{ Gastrointestinal } & Antiemetic & Droperidol \\
\hline & & Ondansetron \\
\hline & & Dolasetron \\
\hline & & Granisetron \\
\hline & Motility modifier & Cisapride \\
\hline & & Domperidone \\
\hline Immunosupressants & & Tacrolimus \\
\hline \multirow[t]{5}{*}{ Neurological } & Anticonvulsants & Fosphenytoin \\
\hline & Antimigraine & Naratriptan \\
\hline & & Sumatriptan \\
\hline & & Zolmitriptan \\
\hline & Antispastic & Tizanidine \\
\hline \multirow[t]{13}{*}{ Psychiatric } & Antipsychotics & Chlorpromazine \\
\hline & (including atypicals) & Haloperidol \\
\hline & & Mesoridazine \\
\hline & & Pimozide \\
\hline & & Thioridazine \\
\hline & & Risperidone \\
\hline & & Quetiapine \\
\hline & Antidepressants & Fluoxetine \\
\hline & & Paroxetine \\
\hline & & Sertraline \\
\hline & & Venlafaxine \\
\hline & Sedatives & Chloral hydrate \\
\hline & Mood stabilizers & Lithium \\
\hline Respiratory & Antiasthmatic & Salmeterol/Fluticasone \\
\hline Urological & $\begin{array}{l}\text { Benign prostatic } \\
\text { hypertrophy }\end{array}$ & Alfluzosin \\
\hline \multicolumn{3}{|l|}{ QTc abnormal values } \\
\hline \multicolumn{3}{|l|}{$460 \mathrm{~ms}$ in women } \\
\hline \multicolumn{3}{|l|}{$440 \mathrm{~ms}$ in men } \\
\hline \multicolumn{3}{|c|}{ Values above $500 \mathrm{~ms}$ indicate a significant risk of arrhythmia } \\
\hline \multicolumn{3}{|l|}{ Useful Web sites } \\
\hline www.torsades.org & \multicolumn{2}{|c|}{$\begin{array}{l}\text { Regularly updated list of drugs that may prolong } \\
\text { QTc interval }\end{array}$} \\
\hline www.atforum.com & \multicolumn{2}{|c|}{$\begin{array}{l}\text { Numerous review articles on methadone, including } \\
\text { methadone safety and dosing, methadone-drug } \\
\text { interactions, and methadone and heart health. }\end{array}$} \\
\hline
\end{tabular}

${ }^{*}$ Data from <www.torsades. org $>$ this system can alter the metabolism of methadone causing an increase or decrease in methadone levels. The CYP3A4 isoenzyme appears to be the most important isoenzyme with regard to methadone metabolism. Thus most of methadone's interactions are related to inducers or inhibitors of CYP3A4, although CYP2D6 and CYP1A2 may also be a factor with some drugs. Drug interactions with methadone have been presented in detail in previous reviews (5) and will be summarized here. Tables 7 and 8 list drugs that may interact with methadone (they are not exhaustive lists). When using other drugs in combination with methadone, clinicians should be aware of the agent's metabolism in the CYP450 system and whether it acts as an inhibitor or inducer of CYP3A4, CYP2D6 or CYP1A2. For inhibitors, methadone levels will go up, while for inducers, methadone levels will go down, and appropriate adjustments will need to be considered.

\section{Contraindications}

Contraindications include a previous allergy to methadone, respiratory depression, severe chronic obstructive pulmonary disease, uncontrolled asthma and concurrent administration with monoamine oxidase inhibitors (15).

\section{REGULATORY ISSUES}

Similar to the situation in many countries, in Canada, methadone requires special authorization for the physician to prescribe it, whether for treatment of opioid addiction or pain. Authorizations are granted under federal authority by the Office of Controlled Substances Methadone Program, issued in the form of exemptions pursuant to Section 56 of the Controlled Drugs and Substances Act (42). Recommendations for exemptions to prescribe methadone have been delegated to the provincial medical licensing authorities (ie, The College of Physicians and Surgeons or equivalent in each province). Thus, in practice, the physician makes an application to the Office of Controlled Substances Methadone Program, which then contacts the appropriate provincial authority asking for a recommendation. It is then up to the provincial licensing authority to make a recommendation. A positive recommendation generally results in an exemption to prescribe methadone, which is then communicated to the physician in the form of a letter copied to the appropriate provincial College of Physicians and Surgeons. The term of the exemption is three years, after which time the physician applies for a renewal.

\section{TREATMENT OF PAIN WITH CHRONIC OPIOIDS}

Canadian Pain Society guidelines

There is a growing body of evidence that controlled-release opioid analgesics have a role to play in a subset of patients with chronic pain (43-50), including those with neuropathic pain $(11,51-56)$. The decision of whether a chronic opioid should be used in a particular patient is beyond the scope of the present review; however, guidelines for the use of opioid analgesics in chronic noncancer pain have been established. Table 9 summarizes the principles of practice for the use of opioid analgesics in chronic noncancer pain, and the reader is referred to the full consensus statement of the Canadian Pain Society for further detail (26). It is important to include a detailed substance abuse history to identify at-risk individuals and to minimize the risk of iatrogenic addiction. 
TABLE 7

Actual or potential methadone drug interactions

\begin{tabular}{|c|c|c|}
\hline & $\begin{array}{l}\text { Medications that decrease } \\
\text { methadone effect }\end{array}$ & $\begin{array}{l}\text { Medications that increase } \\
\text { methadone effect }\end{array}$ \\
\hline \multicolumn{3}{|l|}{ Anti-infectives } \\
\hline Antibiotics & Fusidic acid (Fucidin, Leo Pharma Inc, Canada) & \\
\hline \multirow[t]{2}{*}{ Antifungals } & & Fluconazole (Diflucan, Pfizer Canada Inc, Canada) \\
\hline & & Ketoconazole (Nizoral, McNeil Consumer Healthcare, Canada) \\
\hline Antimalarials & Rifampin & \\
\hline \multirow[t]{6}{*}{ Antiretrovirals } & Abacavir (Ziagen, GlaxoSmithKline Inc, Canada) & Delaviridine (Rescriptor, Pfizer Canada Inc, Canada) \\
\hline & Amprenavir (Agenerase, GlaxoSmithKline Inc, Canada) & \\
\hline & Efarvirenze (Sustiva, Bristol-Myers Squibb, Canada) & \\
\hline & lopinavir/ritonavir (Kaletra, Abbott Laboratories, Canada) & \\
\hline & Nelfinavir (Viracept, Pfizer Canada Inc, Canada) & \\
\hline & Nevirapine (Viramune, Boehringer Ingelheim Ltd, Canada) & \\
\hline Floxins & & Ciprofloxacin (Cipro, Bayer, Canada) \\
\hline \multirow[t]{3}{*}{ Macrolides } & & Azithromycin (Zithromax, Pfizer Canada Inc, Canada) \\
\hline & & Clarithromycin (Biaxin, Abbott Laboratories, Canada) \\
\hline & & Erythromycin \\
\hline \multicolumn{3}{|l|}{ Psychiatric } \\
\hline Antianxiety & & Diazepam (Valium, Hoffmann-La Roche Limited, Canada) \\
\hline \multirow[t]{6}{*}{ Antidepressants* } & & Fluoxetine (Prozac, Eli Lilly Canada Inc, Canada) \\
\hline & & Fluvoxamine (Luvox, Solvay Pharma, Canada) \\
\hline & & Moclobemide (Manerix, Hoffmann-La Roche Limited, Canada) \\
\hline & & Nefazodone (Serzone, Bristol-Myers Squibb, Canada) \\
\hline & & Paroxetine (Paxil, GlaxoSmithKline Inc, Canada) \\
\hline & & Sertraline (Zoloft, Pfizer Canada Inc, Canada) \\
\hline \multirow[t]{5}{*}{ Barbiturates } & Amobarbital sodium (Amytal, Eli Lilly Canada Inc, Canada) & \\
\hline & Butalbital (in Fiorinal, Paladin Laboratories Inc, Canada) & \\
\hline & Pentobarbital (Nembutal, Abbott Laboratories, Canada) & \\
\hline & Phenobarbital & \\
\hline & Secobarbital (Seconal, Eli Lilly Canada Inc, Canada) & \\
\hline \multirow[t]{6}{*}{ Opioids } & Butorphanol & \\
\hline & Buprenorphine & \\
\hline & Naloxone & \\
\hline & Naltrexone & \\
\hline & Nalbuphine & \\
\hline & Pentazocine & \\
\hline \multicolumn{3}{|l|}{ Gastrointestinal } \\
\hline \multirow[t]{2}{*}{ Acid disorders } & & Cimetdine (Tagamet, GlaxoSmithKline Inc, Canada) \\
\hline & & Omeprazole (Losec, AstraZeneca Canada Inc, Canada) \\
\hline \multicolumn{3}{|l|}{ Neurological } \\
\hline Antialcohol & & Disulfiram (Antabuse, Wyeth-Ayerst, Canada) \\
\hline \multirow[t]{2}{*}{ Anticonvulsant } & Carbamazepine (Tegretol, Novartis Pharmaceuticals, Canada) & \\
\hline & Phenytion (Dilantin, Pfizer Canada Inc, Canada) & \\
\hline Antimigraine & & Dihydroergotamine (Migranal, Novartis Pharmaceuticals, Canada) \\
\hline \multicolumn{3}{|r|}{ 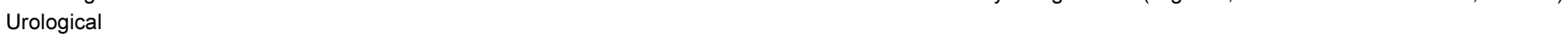 } \\
\hline Diuretics & Spironolactone (Aldactone, Pfizer Canada Inc, Canada) & \\
\hline \multirow[t]{3}{*}{ Urinary acidifiers } & Large dose vitamin $C$ & \\
\hline & Monobasic potassium phosphate (K-Phos, Beach & \\
\hline & Products Inc, USA) & \\
\hline \multirow[t]{2}{*}{ Urinary alkinizers } & & Sodium bicarbonate \\
\hline & & $\begin{array}{l}\text { Potassium citrate (K-Lyte, WellSpring Pharmaceutical } \\
\text { Corporation, Canada) }\end{array}$ \\
\hline \multicolumn{3}{|l|}{ Cardiovascular } \\
\hline Calcium channel blocker & & Verapamil (Isoptin, Abbott Laboratories, Canada) \\
\hline Corticosteroid & Dexamethasone (Decadron, Merck Frosst Canada Ltd, Canada) & \\
\hline \multirow[t]{4}{*}{ Herbal medicines } & St John's Wort & Cat's claw \\
\hline & & Chamomile \\
\hline & & Echinacea \\
\hline & & Goldenseal \\
\hline Drugs of abuse & Alcohol (chronic use) & Alcohol (acute use) \\
\hline & Cocaine & \\
\hline & Heroin & \\
\hline & Tobacco & \\
\hline Food & & Grapefruit juice \\
\hline
\end{tabular}

*The serotonin and noradrenaline reuptake inhibitor venlafaxine has the least potential for interaction with methadone 


\section{TABLE 8}

Actual or potential methadone drug interactions

\begin{tabular}{ll}
\hline Medications whose serum levels are & Desipramine \\
increased by methadone & Zidovudine \\
& Dextromethorphan \\
& Codeine \\
& Hydrocodone \\
& Haloperidol \\
& Phenothiazines \\
& Beta-blockers \\
Medications with additive toxicity & Benzodiazepines* \\
& Monoamine oxidase inhibitors \\
Medications associated with & Delta-9-tetrahydrocannabinol \\
synergistic analgesia & Ibuprofen \\
& Diclofenac \\
\hline
\end{tabular}

${ }^{*}$ Cases of fatal drug overdose have been reported with coadministration with alprazolam because of additive toxicity. Data from references 12 and 15, and www. atforum.com
Comorbid chronic pain and addiction

The assessment of addiction in pain treatment settings has received increasing attention and there are a number of excellent reviews to assist clinicians in the assessment and treatment of patients with comorbid chronic pain and addiction (57-60). The situation may also be complicated by additional psychiatric morbidity, which may also need to be addressed (61). Recent reviews acknowledge the need for further study in these areas $(57,61)$.

Although one might speculate that because methadone maintenance programs have been successful in assisting street drug addicts, that it might be a better choice for patients with comorbid pain and addiction, this is unknown and requires appropriate study. To date, there have been no controlled trials examining the use of methadone in this population nor have

\section{TABLE 9}

Summary of principles of practice for the use of opioid analgesics in chronic noncancer pain from the consensus statement of the Canadian Pain Society

Evaluate the patient

Detailed history and physical

Assessment of impact of pain on significant others

Review previous investigations and assessments and request additional investigations, if necessary, to complete diagnostic workup Assess comorbidity

Establish diagnosis Assess psychological aspects Assess risk of addiction Indications for trial of
opioid therapy

Establish an overall management plan Identify reasonable goals of treatment

Obtain full informed consent

Use time contingent dosing

Consult appropriate pain, addiction or psychological specialists where necessary Periodic review ('5 As') Manage side effects of opioids/lack of efficacy. Document
Identify nociceptive versus neuropathic mechanisms underlying the pain

Identify comorbid psychiatric diagnoses, note that pain leads to psychological suffering and address this aspect in treatment Identify patients who may need a more detailed assessment

Ask: Has your use of alcohol or other drugs ever caused a problem for you or those close to you?

Office screening tools:

Screening Instrument for Substance Abuse Potential (SISAP) ${ }^{\star}$

1. If you drink, how many drinks do you have in a typical day?

2. How many drinks do you have in a typical week?

3. Have you used marijuana or hashish in the past year?

4. Have you ever smoked cigarettes?

5. What is your age?

CAGE-AID ${ }^{\dagger}$

In the past have you ever:

a) felt that you wanted or needed to CUT down on your drinking or drug use?

b) been ANNOYED by other's complaining about your drinking or drug use?

c) felt GUILTY about the consequences of your drinking or drug use?

d) had a drink or drug in the morning (EYE-OPENER) to decrease hangover or withdrawal symptoms?

Patients with a past history of addiction will require more careful prescribing and closer follow-up

Patients with moderate to severe pain that is nociceptive, neuropathic or both

Patients with mild to moderate pain that has failed to respond to other treatments (modaliity based or pharmacological) or have had side effects that limit use

In situations where a definitive diagnosis cannot be established, a trial of opioids requires careful monitoring and specific goals

Treatment with chronic opioids should take place within an overall pain management plan which includes consideration

of all appropriate therapies for that individual patient

Improved pain control is a reasonable and appropriate goal

It is also useful to develop functional goals, however failure to attain all functional goals should not necessarily be construed as therapeutic failure

Review; risks and benefits of opioid therapy including possible side effects, small risk of addiction in low-risk patients, tolerance, physical dependence and withdrawal risk if suddenly discontinued

Risks of additive side effects with other potentially sedating agents

Conditions under which opioids will be prescribed

If concerned about noncompliance consider a written agreement

The goal is to try and keep breakthrough doses to a minimum once stabilization phase is accomplished

This will also depend on availability of the appropriate specialists

Assess Analgesia, Activities, Adverse effects, Abuse behaviours and Adequate documentation

Institute treatment of side effects, if there is a decrease in function or intolerable side effects, gradual reduction of opioid may be indicated

To demonstrate evaluation process, rationale for opioid therapy in context of overall management plan, follow-up and compliance with federal regulations

*Use caution in the following patients: men who exceed four drinks/day or 16 drinks/week; women who exeed three drinks/day or 12 drinks/week; recreational users of marijuana or hashish for euphoriant effects; and patients younger than 40 years of age who smoke. Data from reference $64 .{ }^{\dagger} A$ positive response to any of the CAGE-AID questions would warrant caution. Two or more positive responses would strongly recommend assessment by an addiction specialist before embarking on chronic opioid therapy 
TABLE 10

Patient categories for methadone management of pain

\begin{tabular}{|c|c|c|c|}
\hline & Group I & Group II & Group III \\
\hline Features & $\begin{array}{l}\text { Patients with chronic pain and no } \\
\text { identified risk factors for addiction } \\
\text { beyond that of the general population } \\
\text { (ie, } 10 \% \text { ). }\end{array}$ & $\begin{array}{l}\text { Patients who have past or active } \\
\text { substance dependence (other than } \\
\text { to opioids) including problematic use } \\
\text { of prescription drugs or abuse as } \\
\text { diagnosed in DSM-IV. }\end{array}$ & $\begin{array}{l}\text { Primary opioid addicts who would otherwise qualify for } \\
\text { methadone maintenance for opioid addiction who } \\
\text { also suffer from chronic pain. }\end{array}$ \\
\hline $\begin{array}{c}\text { Approach to } \\
\text { treatment }\end{array}$ & $\begin{array}{l}\text { Methadone would be used as any } \\
\text { other opioid with attention given to } \\
\text { its unique pharmacokinetics and } \\
\text { with care regarding dosage titration. }\end{array}$ & $\begin{array}{l}\text { Clearer limits regarding prescribed } \\
\text { medications are needed. } \\
\text { Use a written agreement with the patient. }\end{array}$ & $\begin{array}{l}\text { In this case, the usual guidelines under the methadone } \\
\text { maintenance program for addiction will apply. } \\
\text { Daily dispensing of opioid medication with first dose } \\
\text { witnessed each day. } \\
\text { After } 2 \text { months on the program with evidence of } \\
\text { stability regarding illicit drug use, patient can be } \\
\text { given full day's methadone ( } 3 \text { doses) for each month } \\
\text { of sustained abstinence. } \\
\text { Consultation with an addiction specialist should occur } \\
\text { where available. }\end{array}$ \\
\hline
\end{tabular}

Data from reference 61. DSM-IV Diagnostic and Statistical Manual of Mental Disorders - Fourth Edition (65)

there been any head to head trials comparing methadone with other opioids in this population. Until studies are available, clinicians may take guidance from the recent reviews noted above, ensuring that a complete assessment of addiction potential is made; that an addiction specialist is consulted when appropriate; that there are clearer limits around the prescribing of medications; that there is limited dispensing, including daily dispensing in some cases; and that there are signed agreements and urine testing in appropriate circumstances. The College of Physicians and Surgeons of Ontario has published guidelines for the use of methadone in chronic pain (62). This document provides a helpful framework when considering comorbid chronic pain and addiction. Table 10 presents three patient categories and summarizes suggested approaches for each category as presented in the Ontario guidelines (62).

When is it reasonable to initiate a trial of methadone?

At present, methadone is considered to be a second-line option in the treatment of cancer pain (13). In addition, as reviewed above, recent literature has identified a role for methadone in treating noncancer pain, neuropathic pain, pain that has failed to respond to conventional opioids and pain in patients for whom opioids have caused toxicity $(10-12,15,16,18)$.

Because methadone has a different structure than conventional phenanthrene opioids (such as codeine, morphine or hydromorphone) and phenylpiperidine opioids (such as fentanyl and mepiridine), methadone may also be used in individuals who have exhibited allergies to conventional opioids. Methadone should be considered in situations where there is a need for cost-effective analgesia and analgesia in renal failure. It may also be reasonable to consider methadone as one of the options in treating moderate to severe pain in individuals who have a history of drug abuse, if a trial of a chronic opioid is deemed appropriate and as long as clinicians establish appropriate limits individualized to that patient's needs to assist in maintaining control over opioid use (see above section on comorbid chronic pain and addiction).

\section{CONCLUSIONS}

Methadone is a unique opioid analgesic with at least three different mechanisms of action in modulation of pain, including potent opioid agonism, NMDA antagonism and a monoaminergic effect. This, in combination with its excellent oral and rectal absorption, high bioavailability, long duration of action and low cost, make it an attractive option for treatment of chronic pain. The disadvantages of significant interindividual variation in pharmacokinetics, graduated dose equivalency ratios based on prior opioid dose when switching from another opioid and the requirement for special exemption for prescribing methadone make it more complicated to use.

The present review has described the literature to date regarding the treatment of chronic cancer and noncancer pain with methadone for physicians interested in adding methadone to their armamentarium in assisting patients with moderate to severe pain. As long as physicians are knowledgeable about methadone's pharmacokinetics and potential interactions, and as long as appropriate dose conversions based on prior opioid dose ratios are used, methadone may be a reasonable therapeutic option with a number of potential advantages for the treatment of chronic noncancer pain.

FUNDING: This review was jointly sponsored by the Department of Psychiatry, Dalhousie University, Halifax, Nova Scotia, and the College of Physicians and Surgeons of Nova Scotia (CPSNS), Halifax, Nova Scotia.

This review was assessed by the CPSNS Ad hoc Committee for the Review of Methadone for Chronic Pain and received formal approval by Council on June 3, 2005.

MEMBERS OF THE CPSNS AD HOC COMMITTEE FOR THE REVIEW OF METHADONE FOR CHRONIC PAIN: Ken Cooper MD (Psychiatric and addictions consultant to the Nova Scotia Prescription Monitoring Program), John Fraser MD (Medical Director, Direction 180), Kevin Keating MD (Deputy Registrar CPSNS), Cameron Little MD (Registrar and CEO of CPSNS and chair of the committee), Mary Lynch MD (Director Research Pain Management Unit, Queen Elizabeth II Health Sciences Centre, Halifax, Nova Scotia), Richard MacLachlin MD (Professor and Head, Department Family Medicine, Dalhousie University, Halifax, Nova Scotia), Patricia Morrison (Manager, Nova Scotia Prescription Monitoring Program), Susan Wedlake MSc RPh (Registrar, Nova Scotia College Pharmacists). 


\section{Appendix A}

\section{Practical tips for prescribing methadone for chronic pain}

Preparation
pothadone comes as a hydrochloride powder that can be mixed with water or a sweetened liquid (traditionally, to reduce abuse
Do not use grapefruit juice.
The pharmacist can prepare it in many concentrations; thus, for patients on higher doses, a higher concentration, such as $5 \mathrm{mg} / \mathrm{mL}$,
$10 \mathrm{mg} / \mathrm{mL}$ or $20 \mathrm{mg} / \mathrm{mL}$, can be used to decrease volumes as necessary.
Metadol (Pharmascience Inc, Canada) is a trade name form of methadone; it is more expensive but is available as tablets as well,
which for some patients is more convenient.
The concentration and dose must be indicated.
The total amount must be indicated.
For repeat prescriptions, a 'partial fill' can be requested by indicating the total amount first and then the part of that amount to be
Prescribing
Indicate that the methadone is being prescribed for pain.
Only one physician should prescribe, so assure the patient has adequate supply for when you are out of the office.
To ensure that your patient receives the least expensive form of methadone, indicate "methadone" on the prescription.
It is best to develop a collaborative relationship with the pharmacist and to contact them by phone to communicate that you
are planning to proceed with a trial of methadone.
Not all pharmacies stock methadone routinely and advance discussion will facilitate smooth initiation and follow-up.
Onmunication with one pharmacy should be used.

\section{Appendix B}

\section{Case study}

Eileen is a 42-year-old mother of three and a disabled nurse who suffers from chronic back and leg pain dating back four years to a work-related lifting injury At that time she was assisting in the transfer of a patient, the individual assisting in the transfer tripped and stumbled, leaving Eileen to bear the full weight of the patient. Eileen experienced a sudden onset of searing pain in the back, and sharp pain and paresthesia radiating into the left leg over the next hour. A subsequent computerized axial tomography scan confirmed a herniated disc. Three months after the onset of the pain, a discectomy was performed. Unfortunately, the pain did not resolve. Eileen worked with physiotherapy, pursued active strategies for pain management and tried to stay active, but the pain was so severe that she was unable to return to work. She was no longer able to toboggan or skate with the kids. She could not attend sports activities with the kids for any longer than $30 \mathrm{~min}$ and the house was a mess. The pain kept her awake at night and she awoke exhausted. Eileen's family physician tried antidepressant analgesics which unfortunately caused palpitations. Gabapentin in a dosage of $300 \mathrm{mg}$ four times daily helped alleviate some of the sharp pain and sensitivity, but the deep, boring, aching pain remained. A trial of Codeine Contin (Purdue Pharma, Canada) up to $200 \mathrm{mg}$ every $12 \mathrm{~h}$ ( $\mathrm{q} 12 \mathrm{~h}$ ) was inadequate and long-acting morphine caused itching and nausea at a dose of $45 \mathrm{mg} \mathrm{q12h}$ while $30 \mathrm{mg}$ doses were inadequate. Eileen's family doctor suggested a trial of methadone. After reviewing the details, Eileen decided she would like to give it a try.

Before switching to methadone, Eileen's dose of opioid included long-acting morphine $45 \mathrm{mg}$ q12h with oral morphine sulphate $10 \mathrm{mg}$ every $4 \mathrm{~h}$ (q4h) as needed for breakthrough pain. She was using approximately $45 \mathrm{mg}$ of breakthrough medication per day.

Methadone calculations:

Step 1 (day 1 to 3 ):

- Replace first one-third of morphine with methadone:

- Total daily dose of morphine includes $90 \mathrm{mg}$ slow (controlled) release morphine $+45 \mathrm{mg}$ morphine sulphate $=135 \mathrm{mg}$

- Decrease the total dose of morphine by $45 \mathrm{mg}(135 \div 3=45)$, leaving a dose of $90 \mathrm{mg}$ long-acting morphine with $45 \mathrm{mg}$ to be replaced by methadone.

- From Table 3 we see that for this patient, a prerotation opioid dose of $8 \mathrm{mg}$ morphine $=1 \mathrm{mg}$ methadone; thus, $45 \mathrm{mg}$ morphine $\div 8=5.6 \mathrm{mg}$ methadone, which is close enough to $6 \mathrm{mg}$ and will, therefore, be given in doses of $2 \mathrm{mg}$ orally every $8 \mathrm{~h}$.

- Allow $10 \%$ of the original opioid dose in the regular preparation q4h when necessary for breakthrough $(135 \mathrm{mg} \div 10=13.5 \mathrm{mg}$, or close whole numbers $)$ throughout the changeover (maximum 4 doses/day).

Step 2 (day 4 to 6):

- Replace the next one-third of the morphine dosage with methadone. Thus, the long-acting morphine dosage will be down to $45 \mathrm{mg} / \mathrm{day}$.

- $90 \mathrm{mg}$ of morphine must now be replaced with methadone using the appropriate conversion, ie, $90 \mathrm{mg} \div 8=11.25 \mathrm{mg}$. Therefore, we will use $12 \mathrm{mg} / \mathrm{day}$ $(4 \mathrm{mg}$ orally every $8 \mathrm{~h}$ )

Step 3 (day 7 onwards):

- Discontinue the long-acting morphine

- Monitor the patient's breakthrough medication needs ( $10 \%$ of original opioid dose in regular preparation $\mathrm{q} 4 \mathrm{~h}$ as needed for breakthrough; $135 \mathrm{mg} \div 10=13.5 \mathrm{mg}$ or close whole numbers, maximum 4 doses/day) and titrate methadone dosage incrementally until pain is controlled without limiting side effects.

- The probable dosing schedule will be approximately $5 \mathrm{mg}$ orally every $8 \mathrm{~h}$ for a total of approximately $15 \mathrm{mg} /$ day. 


\section{REFERENCES}

1. Wolff K, Rostami-Hodjegan A, Shires S, et al. The pharmacokinetics of methadone in healthy subjects and opiate users. Br J Clin Pharmacol 1997;44:325-34.

2. Pasternak G. Multiple morphine and enkephalin receptors and the relief of pain. JAMA 1988;259:1362-7.

3. Pasternak GW. Incomplete cross tolerance and multiple mu opioid peptide receptors. Trends Pharmacol Sci 2001;22:67-70.

4. Ebert B, Andersen S, Krogsgaard-Larsen P. Ketobemidone, methadone and pethidine are non-competitive $\mathrm{N}$-methyl-Daspartate (NMDA) antagonists in the rat cortex and spinal cord. Neurosci Lett 1995;187:165-8.

5. Davis AM, Inturrisi CE. d-Methadone blocks morphine tolerance and $\mathrm{N}$-methyl-D-aspartate-induced hyperalgesia. J Pharmacol Exp Ther 1999;289:1048-53.

6. Codd EE, Shank RP, Schupsky JJ, Raffa RB. Serotonin and norepinephrine uptake inhibiting activity of centrally acting analgesics: Structural determinants and role in antinociception. J Pharmacol Exp Ther 1995;274:1263-70.

7. Callahan RJ, Au JD, Paul M, Liu C, Yost CS. Functional inhibition by methadone of $\mathrm{N}$-methyl-D-aspartate receptors expressed in Xenopus oocytes: Stereospecific and subunit effects. Anesth Analg 2004;98:653-9.

8. Ebert B, Thorkildsen C, Andersen S, Christrup LL, Hjeds H. Opioid analgesics as noncompetitive $\mathrm{N}$-methyl-D-aspartate (NMDA) antagonists. Biochem Pharmacol 1998;56:553-9.

9. Gorman A, Elliott K, Inturrisi C. The d-and l-isomers of methadone bind to the non-competitive site on the $\mathrm{N}$-methyl-D-aspartate (NMDA) receptor in rat brain and spinal cord. Neurosci Lett 1997;223:5-8.

10. Gagnon B, Almahrezi A. Methadone in the treatment of neuropathic pain. Pain Res Manage 2003;8:149-54.

11. Moulin D. Use of methadone for neuropathic pain. Pain Res Manage 2003;8:131-2.

12. Bruera E, Sweeney C. Methadone use in cancer patients with pain. J Palliative Med 2002;5:127-37.

13. Ripamonti C, Zecca E, Bruera E. An update on the clinical use of methodone for cancer pain. Pain 1997;70:109-15.

14. Fainsinger R, Schoeller T, Bruera E, Methadone in the management of cancer pain: A review. Pain 1993;52:137-47.

15. Davis M, Walsh D. Methadone for the relief of cancer pain: A review of pharmacokinetics, pharmacodynamics, drug interactions and protocols of administration. Support Care Cancer 2001;9:73-83.

16. Altier N, Dion D, Boulanger A, Choiniere M. Successful use of methadone in the treatment of chronic neuropathic pain arising from burn injuries: A case-study. Burns 2001;27:771-5.

17. Gagnon B, Bruera E. Differences in ratios of morphine to methadone in patients with neuropathic pain versus non-neuropathic pain. J Pain Symptom Manage 1999;18:120-4.

18. Hays H, Woodroffe M. Use of methadone in treating chronic noncancer pain. Pain Res Manage 1999;4:23-7.

19. Kristensen K, Blemmer T, Angelo HR, et al. Stereoselective pharmacokinetics of methadone in chronic pain patients. Ther Drug Monit 1996;18:221-7.

20. Rubenstein RB, Kreek MJ, Mbawa N, Wolff WI, Korn R, Gutjahr CL. Human spinal fluid methadone levels. Drug Alcohol Depend 1978;3:103-6.

21. Bellward GD, Warren PM, Howald W, Axelson JE, Abbott FS. Methadone maintenance: Effect of urinary $\mathrm{pH}$ on renal clearance in chronic high and low doses. Clin Pharmacol Ther 1977;22:92-9.

22. Haley J, Sullivan A, Dickensen A. Evidence for spinal $\mathrm{N}$-methyl-D-aspartate receptor involvement in prolonged chemical nociception in the rat. Brain Res 1990;518:218-26.

23. Dickensen A, Sullivan A. Evidence for a role of the NMDA receptor in the frequency dependent potentiation of deep rat dorsal horn nociceptive neurons following $\mathrm{C}$ fibre stimulation. Neuropharmacology 1987;26:1235-8.

24. Trujillo K, Akil H. Inhibition of opiate tolerance by noncompetitive N-methyl-D-aspartate receptor antagonists. Brain Res 1994;633:178-88.

25. Eilers H, Philip L, Bickler P. The reversal of fentanyl induced tolerance by administration of "small-dose" ketamine. Anesth Analg 2001;93:213-4.

26. Jovey RD, Ennis J, Gardner-Nix J, et al. Use of opioid analgesics for the treatment of chronic noncancer pain - A consensus statement and guidelines from the Canadian Pain Society, 2002. Pain Res Manage 2003;8(Suppl A):3A-28A.
27. Ripamonti C, Groff L, Brunelli C, Polastri D, Stavrakis A, De Conno F. Switching from morphine to oral methadone in treating cancer pain: What is the equianalgesic dose ratio? J Clin Oncol 1998;16:3216-21.

28. Hagan N, Wasylenko E. Methadone: Outpatient titration and monitoring strategies in cancer patients. J Pain Symptom Manage 1999;18:369-75.

29. Mercadante S, Casuccio A, Calderone L. Rapid switching from morphine to methadone in cancer patients with poor response to morphine. J Clin Oncology 1999;17:3307-12.

30. Morley JS, Bridson J, Nash TP, Miles JB, White S, Makin MK. Low-dose methadone has an analgesic effect in neuropathic pain: A double-blind randomized controlled crossover trial. Palliat Med 2003; 17:576-87.

31. Bruera E, Pereira J, Watanabe S, Belzile M, Kuehn N, Hanson J. Opioid rotation in patients with cancer pain. A retrospective comparison of dose ratios between methadone, hydromorphone, and morphine. Cancer 1996;78:852-7.

32. Lawlor PG, Turner KS, Hanson J, Bruera ED. Dose ratio between morphine and methadone in patients with cancer pain: A retrospective study. Cancer 1998;82:1167-73.

33. Mercadante S, Casuccio A, Fulfaro F, et al. Switching from morphine to methadone to improve analgesia and tolerability in cancer patients: A prospective study. J Clin Oncol 2001;19:2898-904.

34. Mercadante S, Casuccio A, Agnello A, Barresi L. Methadone response in advanced cancer patients with pain followed at home. J Pain Symptom Manage 1999;18:188-92.

35. Bruera E, Watanabe S, Fainsinger RL, Spachynski K, Suarez-Almazor M, Inturrisi C. Custom-made capsules and suppositories of methadone for patients on high-dose opioids for cancer pain. Pain 1995;62:141-6.

36. Daeninck P, Watanabe S, Walker P, Bruera E. Effective pain relief in cancer patients using methadone at extended dosing intervals. J Palliat Care 1998;13:117.

37. Walker P, Klein D, Kasza L. High dose methadone and ventricular arrythmias: A report of three cases. Pain 2003;103:321-4.

38. Krantz MJ, Lewkowiez L, Hays H, Woodroffe MA, Robertson AD, Mehler PS. Torsade de pointes associated with very-high-dose methadone. Ann Intern Med 2002;137:501-4.

39. Krantz MJ, Kutinsky IB, Robertson AD, Mehler PS. Dose-related effects of methadone on QT prolongation in a series of patients with torsade de pointes. Pharmacotherapy 2003;23:802-5.

40. Martell B, Ray B, Gourevitch M. The impact of methadone induction on cardiac conduction in opiate users. Ann Int Med 2003;139:154-5.

41. Maremmani I, Pacini M, Cesaroni C, Lovrecic M, Perugi G, Tagliamonte A. QTc interval prolongation in patients on long-term methadone maintenance therapy. Eur Addict Res 2005;11:44-9.

42. Canadian Department of Justice. Controlled Drugs and Substances Act. $<$ laws.justice.gc.ca/en/C-38.8/> (Version current at June 3, 2005).

43. Allan L, Hays H, Jensen NH, et al. Randomised crossover trial of transdermal fentanyl and sustained release oral morphine for treating chronic non-cancer pain. BMJ 2001;322:1154-8.

44. Jamison RN, Raymond SA, Slawsby EA, Nedeljkovic SS, Katz NP. Opioid therapy for chronic noncancer back pain. A randomized prospective study. Spine 1998;23:2591-600.

45. Caldwell JR, Hale ME, Boyd RE, et al. Treatment of osteoarthritis pain with controlled release oxycodone or fixed combination oxycodone plus acetaminophen added to nonsteroidal antiinflammatory drugs: A double blind, randomized, multicenter, placebo controlled trial. J Rheumatol 1999;26:862-9.

46. Caldwell JR, Rapoport RJ, Davis JC, et al. Efficacy and safety of a once-daily morphine formulation in chronic, moderate-to-severe osteoarthritis pain: Results from a randomized, placebo-controlled, double-blind trial and an open-label extension trial. J Pain Symptom Manage 2002;23:278-91.

47. Hale ME, Fleischmann R, Salzman R, et al. Efficacy and safety of controlled-release versus immediate-release oxycodone: Randomized, double-blind evaluation in patients with chronic back pain. Clin J Pain 1999;15:179-83.

48. Peloso PM, Bellamy N, Bensen W, et al. Double blind randomized placebo control trial of controlled release codeine in the treatment of osteoarthritis of the hip or knee. J Rheumatol 2000;27:764-71.

49. Roth SH, Fleischmann RM, Burch FX, et al. Around-the-clock, controlled-release oxycodone therapy for osteoarthritis-related pain: 
Placebo-controlled trial and long-term evaluation. Arch Intern Med 2000;160:853-60.

50. Babul N, Noveck R, Chipman H, Roth SH, Gana T, Albert K. Efficacy and safety of extended-release, once-daily tramadol in chronic pain: A randomized 12-week clinical trial in osteoarthritis of the knee. J Pain Symptom Manage 2004;28:59-71.

51. Raja SN, Haythornthwaite JA, Pappagallo M, et al. Opioids versus antidepressants in postherpetic neuralgia: a randomized, placebocontrolled trial. Neurology 2002;59:1015-21.

52. Huse E, Larbig W, Flor H, Birbaumer N. The effect of opioids on phantom limb pain and cortical reorganization. Pain 2001;90:47-55.

53. Watson CP, Babul N. Efficacy of oxycodone in neuropathic pain: A randomized trial in postherpetic neuralgia. Neurology 1998;50:1837-41.

54. Watson CP, Moulin DE, Watt-Watson J, et al. A randomized, double-blind crossover comparison of the efficacy and safety of oral controlled-release oxycodone and active placebo in patients with painful diabetic neuropathy. J Pain 2001;2(Suppl 1):43. (Abst)

55. Gimbel JS, Richards P, Portenoy RK. Controlled-release oxycodone for pain in diabetic neuropathy. Neurology 2003;60:927-34.

56. Rowbotham MC, Twilling L, Davies PS, Reisner L, Taylor K, Mohr D. Oral opioid therapy for chronic peripheral and central neuropathic pain. N Engl J Med 2003;348:1223-32.

57. Savage SR. Assessment for addiction in pain treatment settings. Clin J Pain 2002;18:S28-38.
58. Savage SR, Joranson DE, Covington EC, Schnoll SH, Heit HA, Gilson AM. Definitions related to the medical use of opioids: Evolution towards universal agreement. J Pain Symptom Manage 2003;26:655-67.

59. Kirsh KL, Whitcomb LA, Donaghy K, Passik SD. Abuse and addiction issues in medically ill patients with pain: Attempts at clarification of terms and empirical study. Clin J Pain 2002;18(Suppl 4):S52-60.

60. Weaver M, Schnoll S. Abuse liability in opioid therapy for pain treatment in patients with an addiction history. Clin J Pain 2002;18:S61-9.

61. Strain E. Assessment and treatment of comorbid psychiatric disorders in opioid-dependent patients. Clin J Pain 2002;18:S14-27.

62. Methadone for Pain Guidelines. Facilitated by the Ontario College of Physicians ad Surgeons. 2004. <www.cpso.on.ca/Publications/ methpain.htm $>$ (Version current at May 31, 2005).

63. Ripamonti C, De Conno F, Groff L, et al. Equianalgesic dose/ratio between methadone and other opioid agonists in cancer pain: Comparison of two clinical experiences. Ann Oncol 1998;9:79-83.

64. Coambs RE, Jarry JL, Santhiapillai AC, Abrahamsohn RV, Atance CM. The SISAP: A new screening instrument for identifying potential opioid abusers in the management of chronic nonmalignant pain in general medical practice. Pain Res Manage 1996;1:155-62.

65. Diagnostic and Statistical Manual of Mental Disorders Fourth Edition (DSM-IV). Washington: American Psychiatric Association, 1994. 


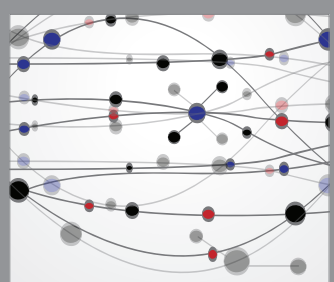

The Scientific World Journal
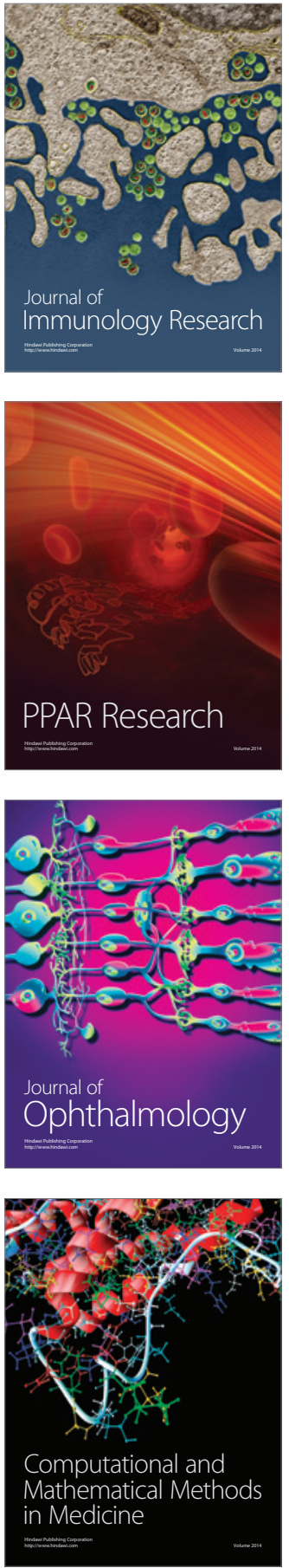

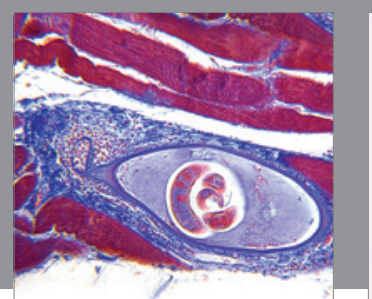

Gastroenterology Research and Practice

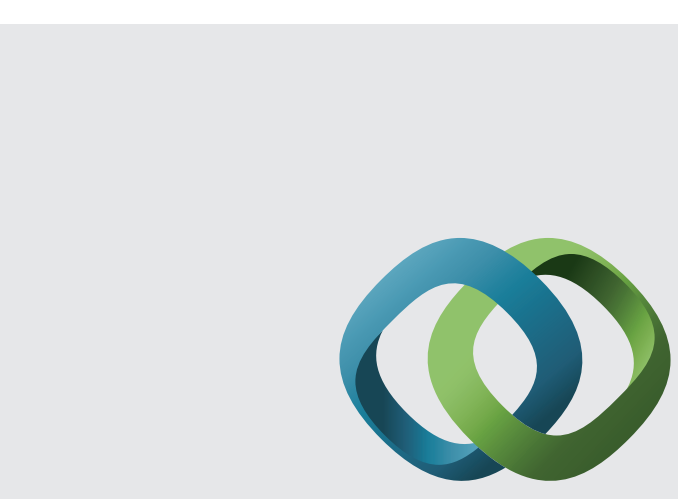

\section{Hindawi}

Submit your manuscripts at

http://www.hindawi.com
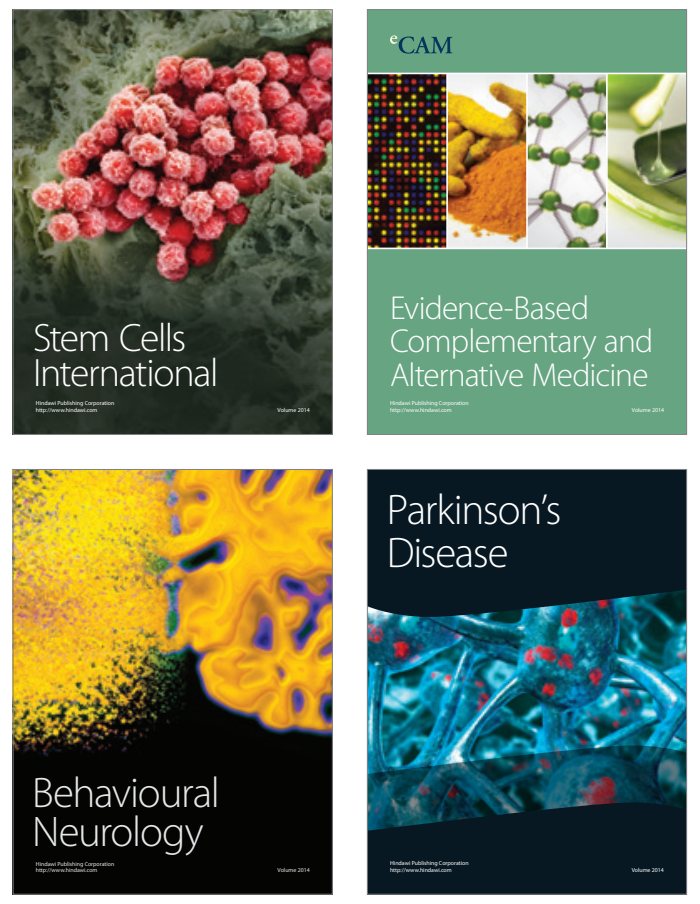
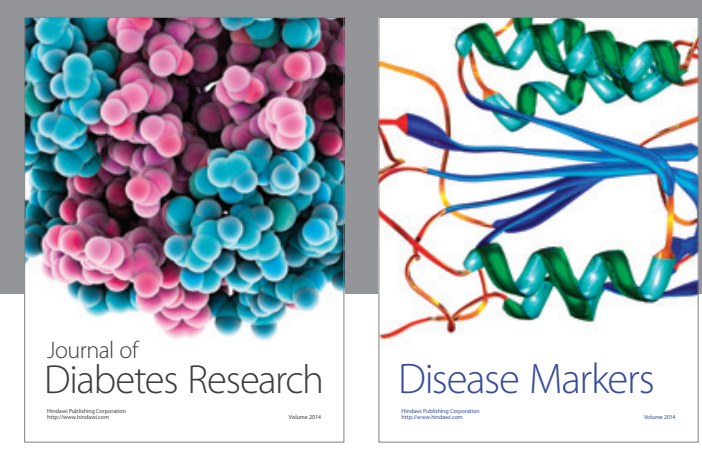

Disease Markers
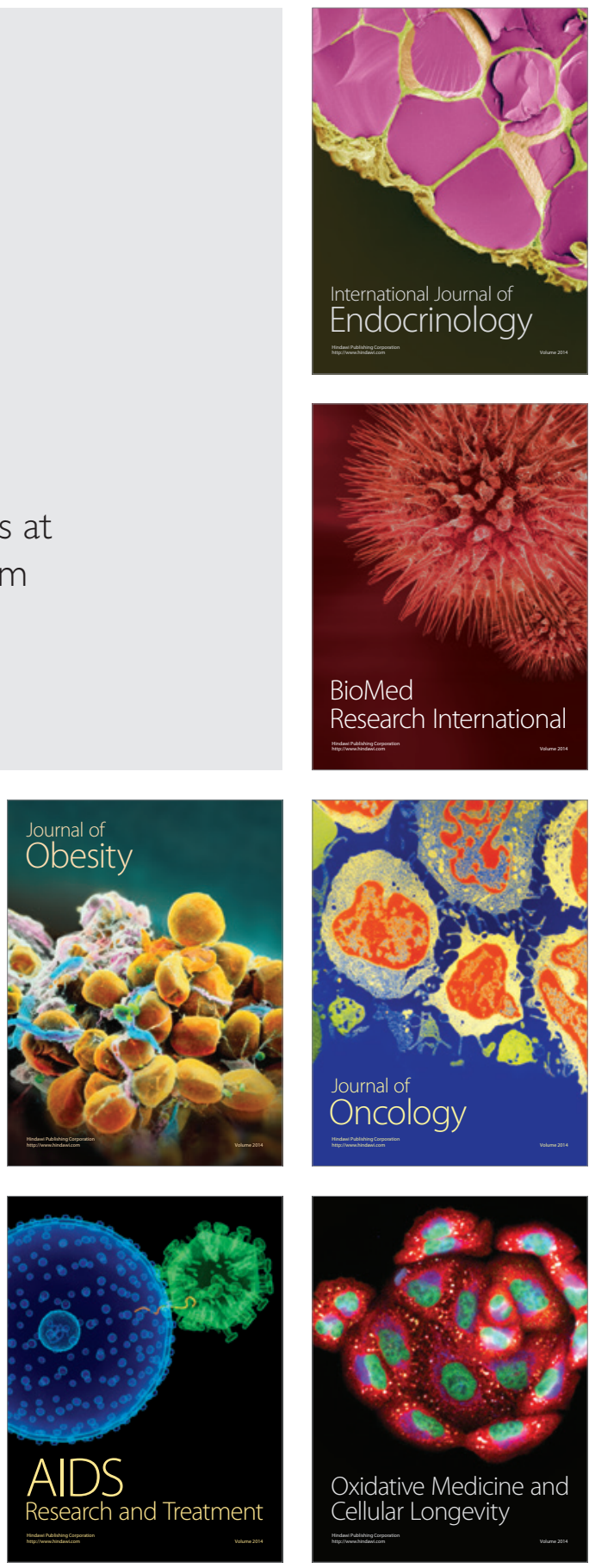